\title{
Irradiation Shared Resource
}

National Cancer Institute

\section{Source}

National Cancer Institute. Irradiation Shared Resource. NCI Thesaurus. Code C39437.

The Irradiation Shared Resource provides Cancer Center investigators with support in the following areas: cell, tumor, specimen, animal irradiation for studies of radiobiologic mechanisms or to suppress immune responses in experimental animals, as well as to sterilize various cell, vaccine and drug preparations; radiotherapy models development and treatment planning, laser and photodynamic therapy, in vivo imaging, in vivo fluorescent imaging, atomic absorption spectroscopy, DNA damage and other radiation assays, safety training and dosimetry measurements. 